\title{
'N 'N ONDERSOEK NA DIE GEHALTE VAN INTERHOSPITAALVERVOER VAN SIEK NEONATE DEUR GESELEKTEERDE AMBULANSE AAN DIE WITWATERSRAND
}

\author{
J.C. Roux, A.G.W. Nolte, M.E. Muller
}

\section{Uittreksel}

Die gehalte interhospitaalvervoer van siek neonate, deur geselekteerde ambulanse, is in die Witwatersrandarea by wyse van die gevallestudie metode ondersoek. In die vyftien gevallestudies wat ondersoek is, is elf neonate deur ' $n$ privaatambulans en vier deur provinsiale ambulanse vervoer. Data ten opsigte van moederlike- en neonatale geskiedenis, die optimale handhawing van die neonaat se toestand, kommunikasie-stelsel, asook aspekte rakende die vervoerpersoneel, is deur middel van 'n gestruktureerde instrument ingesamel. Retrospektiewe ouditering van rekords, gestruktureerde onderhoudvoering en direkte warneming/inspeksie is as navorsingstegnieke gebruik. Die gehalte interhospitaalvervoer van siek neonate is, veral deur die privaatambulans, nie na wense nie. Dit is veral die neonate se liggaamstemperatuur, hart-en asemhalingspoed, asook bloedglukosewaardes wat agteruitgang ná vervoer getoon het. Die gebrek aan toerusting, deur veral die privaatambulans, verhoog die risiko van vervoer. Personeelontwikkeling en formele beheer deur 'n plaaslike komitee en 'n nasionale beheerliggaam, word aanbeveel.

\section{Abstract \\ The quality of the inter hospital transport of ill neonates, by selected ambulances in the Witwatersrand area, was investigated by means of the case study method. Of the fifteen case studies investigated, eleven neonates were transported by a private ambulance and four by provincial ambulances. Data regarding the} maternal-and neonatal history, the optimal maintenance of the neonate's condition, the communication system. as well as aspects relating to the transport personnel, were collected by means of a structured instrument. Retrospective auditing of records, structured interviewing and direct observation/inspection were utilised as the research techniques. The quality of the inter hospital transport of ill neonates, especially by the private ambulance, is not up to standard. Deterioration of the neonate's body temperature, heart and respiration rates, as well as the serum glucose values after transport, were of the more important findings. The lack of equipment, especially in the private ambulance, increases the risk of transport. Staff development and formal control by a local committee, as well as a national control body, are recommended.

\section{INLEIDING}

Die koste van gesofistikeerde neonatale intensiewe sorg, asook die geografiese beskikbaarheid van gespesialiseerde gesondheidsmannekrag, bemoeilik die lewering van hierdie dienste in alle hospitale.

Gedurende die afgelope twintig jaar is geweldige vooruitgang gemaak in die kennis van patofisiologie en afwykings uniek aan die premature baba. Nuwe tegnieke is ontwikkel in die intensiewe sorg van die pasgeborene, wat insluit die voortdurende monitering van vitale tekens, bloedgasse en suurbasisewewig, asook intermitterende positiewe drukventilasie in die behandeling van respiratoriese gebreke (5: 34). Hierdie tegnieke is hoogs gespesialiseerd en tydrowend. ' $n$ Selfs groter aantal hoogs gespesialiseerde verpleegkundiges en mediese praktisyns word vereis as wat in talle van die fasiliteite voorsien kan word. Verder word hoogs gespesialiseerde dienste vereis, byvoorbeeld laboratoria wat mikro-en ultramikromonsters kan hanteer en 'n radiologiese diens wat op 'n vier-en- twintiguur basis beskikbaar is $(5: 34 ; 6$ : 419).

Dit is dus onvermydelik dat kritiek siek neonate vanaf een hospitaal na 'n ander vervoer moet word. Die handhawing van die siek neonaat se temperatuur, suurbasisewewig, vog- en elektrolietbalans, asook asemhaling, is kritiese faktore tydens die vervoer van hierdie neonate.

Aangesien die vervoermiddel 'n voortsetting van 'n neonatale intensiewe sorgeenheid is, is die toerusting, voorrade, die kundigheid en vaardigheid van die vervoerpersoneel, asook die kommunikasiestelsel, kritiese faktcre wat bepalend in die effektiwiteit van interhospitaalvervoer van siek neonate is $(1: 337 ; 8$ : 32-34).

Die vervoer van 'n siek neonaat is opsigself 'n probleem aangesien dit die fisiese toestand van die baba kan verswak en die mortaliteit van babas verhoog (3: 147-149). Schreiner (7: 154) is van mening dat 'n siek neonaat liewers by sy hospitaal van oorsprong gelaat moet word as hy nie na wense vervoer kan word nie, omdat geen intensiewe sorgeenheid hipoksiese breinskade wat reeds plaasgevind het, kan ophef nie.

Neonatale intensiewe sorg word net by streeksentra gelewer en gevolglik het die vervoer van babas na hierdie sentra 'n praktiese en realistiese verwagting geword. Die feit dat babas se vitale tekens verder van die normale spektrum verwyder is nadat vervoer plaasgevind het as wat vóór die vervoer die geval was, het die vraag laat ontstaan of die ambulansdienste voldoende toegerus is om siek neonate, veral in die Witwatersrand area, te vervoer.

Die doel van hierdie ondersoek is om die gehalte van interhospitaalvervoer van siek neonate, aan die Witwatersrand, te ondersoek.

\section{DEFINIERING VAN TERME}

Neonaat

'n Baba word vanaf die tydstip van geboorte totdat 'n ouderdom van vier weke of 28 dae bereik word, as 'n neonaat bestempel. 


\section{Gehalte}

Gehalte verwys na die kenmerke van voortreflikheid en die konformering van voorafbepaalde standaarde.

\section{Interhospitaalvervoer}

Dit is die vervoer van 'n neonaat vanaf een hospitaal na 'n ander, vir die doel van hierdie ondersoek, per grondambulans.

\section{NAVORSINGSMETODE}

Nadat standaarde vir die interhospitaalvervoer van siek neonate geformuleer en gevalideer is, is die gehalte van hierdie vervoer deur middel van die gevallestudie metode ondersoek.

Die steekproefpopulasie wat in hierdie ondersoek gebruik is, sluit alle hospitale aan die Witwatersrand in wat oor neonatale intensiewe sorgeenhede beskik. Verder sluit dit ook alle ambulansdienste aan die Witwatersrand, provinsiaal en privaat, wat siek neonate van een hospitaal na ' $n$ ander vervoer, in.

Twee hospitale is vanuit die steekproefpopulasie doelgerig geselekteer waar die gevallestudies gedoen is. 'n Privaat- en provinsiale hospitaal is, op grond van hul toeganklikheid en frekwensie van vervoergevalle, in die steekproef ingesluit. Alle neonate (ook steekproefpersone genoem) wat gedurende die tydperk Mei tot Junie 1987 na hierdie hospitale vervoer is, het as ontledingseenheid vir die gevallestudies gekwalifiseer.

'n Gestruktureerde vraelys is, aan die hand van die geformuleerde standaarde, as evalueringsinstrument ontwerp. Die vraelys is in drie afdelings verdeel en in elke afdeling is van verskeie evalueringstegnieke gebruik gemaak:

- In afdeling $A$ is van retrospektiewe ouditering gebruik gemaak en die vitale tekens en toestand van die baba, vóor en ná vervoer, is beoordeel. Die rekords aangaande die baringsgeskiedenis, gestasie-ouderdomme, gewig,

apgartellings, asook die siekte-toestand van die steekproefpersone is ook beoordeel.

- Afdeling B het oor die gehalte van vervoer gehandel en is by wyse van gestruktureerde onderhoudvoering beoordeel. Die gehalte van die kommunikasiestelsel, toerusting en enkele personeelaspekte, is geëvalueer. Die kennis en vaardighede van die vervoerpersoneel is nie in hierdie studie ondersoek nie.

- Direkte waarneming is as evalueringstegniek in afdeling $C$ geselekteer om, by wyse van 'n kontrole-lys, die beskikbaarheid en aard van toerusting en voorrade in die ambulanse te beoordeel. Twee waarnemers is vir hierdie deel van die ondersoek gelyktydig vir elke vervoergeva] gebruik. Statistiese korrelasieberekeninge van die interwaarnemerbetroubaarheid is op grond van die klein steekproefgrootte $(\mathbf{N}=15)$ verwerp.

'n Loodsondersoek van die dataversamelingsinstrument is uitgevoer om die duidelikheid en volledigheid van die instrument te verseker. Hierdie

loodsondersoek is in drie hospitale, wat nie by die steekproef betrokke was nie, op vyf vervoergevalle uitgetoets. Geen strukturele veranderinge is aangebring nie.

Die betroubaarheid van die evalueringsinstrument is deur die Küder-Richardson korrelasie koëffisiënt (KR-20) van 0,995 bevestig.

\section{RESULTATE}

Vyftien gevallestudies is ondersoek waarvan elf van die steekproefpersone (neonate) deur die privaat- en vier deur provinsiale ambulanse vervoer is. Die afstand wat deur die ambulanse afgele is, wat ' $n$ belangrike eksterne veranderlike in die studie kan wees, het tussen twintig en tagtig kilometer gewissel, waarvan die meeste (ses) vervoergevalle minder as twintig kilometer afgelê het. Geen oponthoude het tydens die vervoergevalle plaasgevind nie.

\section{Moederlike geskiedenis}

Van die vyftien vervoergevale is elf van die steekproefpersone by wyse van spontane baring en een deur ' $n$ elektiewe keisersnit gebore. Die inligting van een van die moeders was nie aangeteken nie. Ses van die moeders wat in spontane baring gegaan het was in premature baring met ' $n$ gestasie-ouderdom van onder ses-en-dertig weke. Nege van die steekproefpersone was voltydse babas.

Die beskikbaarheid van inligting met betrekking tot die moederlike geskiedenis van de steekproefpersone het leemtes getoon. Belangrike inligting soos die ruptuur van vliese, duur van die ruptuur, die hoeveelheid amnionvog en die aard van die amnionvog, was telkens in minder as die helfte van die vervoergevalle beskikbaar. Inligting oor die tipe verlossing was slegs in tien van die vyftien vervoergevalle beskikbaar. 'n Gebrek aan hierdie tipe inligting lei tot die onnodige blootstelling van siek neonate aan vervoer wat reeds voor die bevalling na sentra met gespesialiseerde dienste oorgeplaas kon word.

\section{Neonatale data}

Hierdie deel van die ondersoek het ten doel gehad om vas te stel of die neonaat in 'n optimale toestand verkeer het alvorens vervoer ' $n$ aanvang geneem het. Neonatale data is ook ná vervoer beoordeel ten einde die gehalte vervoer te evalueer.

In vyf van die vervoergevalle was prematuriteit en gevolglike respiratoriese nood die oorsaak van siekte. Een was as gevolg van gastro-intestinale probleme vervoer en in ses van die gevalle was kardio-vaskulêre abnormaliteite die hoofoorsaak van die siekte. Drie van die steekproefpersone het kongenitale abnormaliteite gehad.

Tien van die steekproefpersone se gewig was minder as drie kilogram, wat hulle meer waarskynlike kandidate vir swak temperatuurkontrole maak as gevolg van min subkutane vet.

Inligting met betrekking tot die steekproefpersone se apgartellings was in al die vervoergevalle toereikend. Nie een van die steekproefpersone moes direk na geboorte aktief geresussiteer word deur intubering of hartmassering nie, aangesien almal 'n apgartelling van meer as ses gehad het na een minuut.

In sewe van die gevalle wat ondersoek is, het die prevervoer temperatuur van die steekproefpersone buite die normale spektrum van $36-37^{\circ} \mathrm{C}$ geval. Hierdie vervoergevalle is deur die privaatambulans vervoer (vergelyk tabel 1). Elf van die steekproefpersone, almal deur die privaatambulansvervoer, se temperatur het buite die normale spektrum van 36$37^{\circ} \mathrm{C}$ geval nadat vervoer plaasgevind het.

Die normale fisiologiese reaksie van die steekproefpersone se liggame op temperatuurverandering het waarskynlik die versnelde hartspoed en respiratoriese spoed, wat ná vervoer voorgekom het, tot gevolg gehad. Tabel 2 reflekteer die fluktuasie in die steek proefpersone se harten respiratoriese spoed vóór en ná vervoer. Steekproefpersone wat deur die provinsiale ambulans vervoer is, toon minder fluktuasie in hierdie vitale tekens as die wat deur die privaatambulans vervoer is.

Geen veranderinge het in die aard van die steekproefpersone se asemhaling vóór en ná vervoer plaasgevind nie. Die steekproefpersone wat vóór vervoer rib- en sternale retraksie of ekspiratoriese steun getoon het, het ook hierdie tekens ná vervoer getoon. So ook het die kliniese kleur van die steekproefpersone na afloop van die vervoer dieselfde gebly, wat tussen pienk, perifere sianose en sentrale sianose gewissel het. Al die steekproefpersone wat deur die provinsiale ambulans vervoer is, naamlik vier, was tydens die vervoer meganies geventileer en dié wat deur die privaatambulans vervoer is het suurstof by 
TABEL 2.

Hart- en respiratoriese spoed van steekproefpersone vóor en ná vervoer

Hartspoed

Minder as 100

$101-120$

$121-160$

161 en meer

Totaal

Respiratoriese spoed

$0-20$

$21-30$

$31-50$

$51-60$

61 en meer

Totaal Private instansie

Voor
0
2
9
0

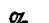

$\% \quad \mathbf{N a}$

$\begin{array}{rr}0,0 & 0 \\ 13,3 & 0 \\ 60,0 & 5\end{array}$

Provinsiale instansie

$\begin{array}{lll}60,0 & 5 & 33,3\end{array}$

$\mathrm{N}=11$

$\begin{array}{rr}0,0 & 0 \\ 0,0 & 1 \\ 13,3 & 2 \\ 60,0 & 1 \\ 0,0 & 7\end{array}$

$\%$
0,0
6,7
13,3
6,7
46,7

$\mathrm{N}=11$

$\%$
0,0
0,0
33,3
40,0

$\% \quad \mathrm{Na}$

\begin{tabular}{rcr}
$\%$ & Na & $\%$ \\
0,0 & 0 & 0,0 \\
6,7 & 1 & 6,7 \\
20,0 & 3 & 20,0 \\
0,0 & 0 & 0,0 \\
\multicolumn{2}{r}{$\mathbf{N}=\mathbf{4}$} & \\
$\%$ & Na & $\%$ \\
0,0 & 0 & 0,0 \\
0,0 & 0 & 0,0 \\
13,3 & 1 & 6,7 \\
13,3 & 3 & 20,0 \\
0,0 & 0 & 0,0
\end{tabular}

$\mathrm{N}=\mathbf{4}$
TABEL 4.

Kommunikasie

Aard van kommunikasie

Mediese praktisyn tref reeling

Ambulanspersoneel kontak

neonatale eenheid

Kommunikasiestelsel

Mediese praktisyn beskikbaar

Multidissiplinêre komitee

Vervoerreélings gedokumenteer

Inligting gedokumenteer

- naam van baba

- moederlike geskiedenis

- bevallingsbesonderhede

- vitale tekens voor vervoer

- vitale tekens tydens vervoer

- behandeling voor vervoer

- behandeling tydens vervoe

Ambulanspersoneel verseker

volledigheid van

oorplasingsdokumente

Skriftelike toestemming vir

vervoer en behandeling

Ambulanspersoneel kontak

ouers

Inligtingstukke beskikbaar

\begin{tabular}{|c|c|c|c|}
\hline \multicolumn{2}{|c|}{$\begin{array}{c}\text { Private } \\
\text { instansie }\end{array}$} & \multicolumn{2}{|c|}{$\begin{array}{c}\text { Provinsiale } \\
\text { instansie }\end{array}$} \\
\hline $\begin{array}{l}\mathbf{J a} \\
(\mathbf{N}\end{array}=$ & $\begin{array}{l}\text { Nee } \\
\text { 11) }\end{array}$ & & $\begin{array}{l}\text { Nee } \\
\text { 4) }\end{array}$ \\
\hline 11 & 0 & 4 & 0 \\
\hline 11 & 0 & 4 & 0 \\
\hline 11 & 0 & 4 & 0 \\
\hline 11 & 0 & 4 & 0 \\
\hline 0 & 11 & 0 & 4 \\
\hline 0 & 11 & 4 & 0 \\
\hline 11 & 0 & 4 & 0 \\
\hline 0 & 11 & 4 & 0 \\
\hline 0 & 11 & 4 & 0 \\
\hline 0 & 11 & 4 & 0 \\
\hline 0 & II & 4 & 0 \\
\hline 0 & 11 & 4 & 0 \\
\hline 0 & 11 & 4 & 0 \\
\hline 11 & 0 & 4 & 0 \\
\hline 0 & 11 & 0 & 4 \\
\hline 0 & 11 & 4 & 0 \\
\hline 0 & 11 & 4 & 0 \\
\hline
\end{tabular}
waarskynlik omdat 'n gestandaardiseerde verwysingsvorm in hierdie verband gebruik word. In die geval van die privaatambulans is ook van 'n vorm gebruik gemaak, maar die inligting wat daarop weergegee word, is hoofsaaklik administratief van aard, soos die adres van die steekproefpersoon, naam van die mediese bystandsfonds en so meer. Geen inligting oor die monitering van die steekproefpersoon se vitale tekens tydens vervoer is dus beskikbaar nie.

'n Ander aspek wat na vore gekom het as 'n moontlike leemte in die

kommunikasie was die feit dat geen multidissiplinêre komitee bestaan wat vervoerprobleme, van veral siek neonate, bespreek nie.

Verder is geen skriftelike toestemming van die ouers verkry vir die vervoer of behandeling van die steekproefpersone nie met gevolglike regs-aanspreeklike risiko's deur die vervoerpersoneel. dehidrasie tydens vervoer. Nadat vervoer deur die privaatambulans plaasgevind het, was slegs vier van die oorspronklike agt intra-veneuse infusies nog in werkende toestand. Dit kan moontlik toegeskryf word aan die feit dat die infusiespoed slegs in drie gevalle gereguleer is. Die vier steekproefpersone wat deur die provinsiale ambulans vervoer is, het almal infusies in werking gehad en dat was nadat vervoer voltooi is, steeds in 'n goeie werkende toestand (vergelyk tabel 3).

\section{Kommunikasie}

Uit die resultate soos in tabel 4 gereflekteer word, blyk die verbale kommunikasie redelik goed te wees. Die skriftelike kommunikasie skyn egter minder volledig

\section{Toerusting}

In hierdie afdeling is die onderhoudvoering met die ambulanspersoneel en die direkte inspeksie van die toerusting gekombineer. Uit tabel 5 blyk dit dat die provinsiale ambulans oor al die nodige toerusting beskik. Dit was met onderhoudvoering en met inspeksie egter duidelik dat daar wel 'n probleem is met beligting binne die ambulans, asook met ruimte, wat 'n probleem tydens 'n noodgeval kan wees. Die beskikbaarheid van kundige vervoerpersoneel is afhanklik van hoe besig die verpleegpersoneel in die neonatale intensiewe sorgeenheid was wat,

TABEL 3.

Vloeistoftoediening

Intra-veneuse oorgieting

Area gesond

Infusiepomp gebruik

\begin{tabular}{|c|c|c|c|}
\hline & \multicolumn{3}{|c|}{ Private instansie $(\mathrm{N}=11)$} \\
\hline & Voor & \multicolumn{2}{|c|}{$\mathbf{N a}$} \\
\hline $\mathbf{J}_{\mathbf{a}}$ & Nee & $\mathbf{J a}$ & Nee \\
\hline $\begin{array}{l}8 \\
8 \\
6\end{array}$ & $\begin{array}{l}3 \\
0 \\
2\end{array}$ & $\begin{array}{l}7 \\
4 \\
3\end{array}$ & $\begin{array}{l}4 \\
3 \\
4\end{array}$ \\
\hline
\end{tabular}

\begin{tabular}{|c|c|c|c|c|}
\hline \multirow[b]{2}{*}{ Toerusting } & \multirow{2}{*}{\multicolumn{2}{|c|}{$\begin{array}{l}\text { Privaat } \\
\mathrm{J}_{\mathbf{a}} \quad \text { Nee } \\
(\mathbf{N}=11)\end{array}$}} & \multicolumn{2}{|c|}{ Provinsiaal } \\
\hline & & & & $\begin{array}{l}\text { Nee } \\
=4)\end{array}$ \\
\hline Twee toegeruste voertuie & 0 & 11 & 4 & 0 \\
\hline Addisionele $\mathrm{O}_{2}$-silinder & 11 & 0 & 4 & 0 \\
\hline 12 Volt kragbron & 11 & 0 & 4 & 0 \\
\hline $\begin{array}{l}\text { Voldoende, sitplek, beligting en } \\
\text { ruimte }\end{array}$ & 0 & 11 & 0 & 4 \\
\hline $\begin{array}{l}\text { Toerusting het selfstandige } \\
\text { kragbronne }\end{array}$ & 0 & 11 & 4 & 0 \\
\hline Vervoerbare suurstofsilinder & 11 & 0 & 4 & 0 \\
\hline Standaard vloeimeter & 11 & 0 & 4 & 0 \\
\hline Suurstofanaliseerder & 0 & 11 & 4 & 0 \\
\hline Kardio-respiratoriese monitor & 11 & 0 & 4 & 0 \\
\hline Ventilator & 11 & 0 & 4 & 0 \\
\hline Intra-veneuse pomp & 0 & 11 & 4 & 0 \\
\hline Volledige suigapparaat & 11 & 0 & 4 & 0 \\
\hline Intubasietoerusting & 11 & 0 & 4 & 0 \\
\hline $\begin{array}{l}\text { Toerusting vir dreinering van } \\
\text { pneumotoraks }\end{array}$ & 0 & 11 & 4 & 0 \\
\hline $\begin{array}{l}\text { Toerusting vir inwerkingstelling } \\
\text { van IV }\end{array}$ & 11 & 0 & 4 & $\mathbf{0}$ \\
\hline $\begin{array}{l}\text { Toerusting vir bepaling van } \\
\text { vitale tekens }\end{array}$ & 0 & 11 & 4 & 0 \\
\hline Noodmedikasie & 11 & 0 & 4 & 0 \\
\hline
\end{tabular}

op aanvraag, die ambulans vergesel het.

Die privaatambulans blyk ontoereikend toegerus te wees. Selfstandige kragbronne by toerusting is afwesig en die vervoerbroeikas beskik nie oor 'n battery nie en kan slegs funksioneer indien dit vanaf die ambulanskrag werk met gevolglike probleme in die handhawing van 'n neonaat se liggaamstemperatuur. Die gebrek aan 'n suurstofanaliseerder, 'n elektroniese infuuspomp, asook noodtoerusting vir intrapleurale dreinering, verhoog die vervoer-risiko van siek neonate deur hierdie ambulans. Dit blyk ook dat die privaatambulans die nasien van toerusting nie in 'n ernstige lig beskou nie (vergelyk tabel 5).

Die broeikas word nie in beide die ambulanse geïmmobiliseer nie. Dit kan 'n gesondheidsgevaar vir die 


\begin{tabular}{|c|c|c|c|c|}
\hline \multirow[b]{3}{*}{ Eienskappe } & \multicolumn{2}{|c|}{$\begin{array}{l}\text { TABEL 6. } \\
\text { Vervoerbroeikas }\end{array}$} & & \\
\hline & \multicolumn{2}{|c|}{ Private instansie } & \multicolumn{2}{|c|}{ Provinsiale instansie } \\
\hline & \multicolumn{2}{|c|}{$(N=11)$} & $(N=4)$ & Nee \\
\hline Immobilisasie in ambuians & 0 & 11 & 0 & 4 \\
\hline Temperatuurhandhawing & 0 & 11 & 4 & 0 \\
\hline Luike & 11 & 0 & 4 & 0 \\
\hline Suurstofinlaatpunt & 11 & 0 & 4 & 0 \\
\hline Alternatiewe openinge & 11 & 0 & 4 & 0 \\
\hline Sigbaarheid & 11 & 0 & 4 & 0 \\
\hline
\end{tabular}

steekproefpersone inhou, veral wanneer die ambulans in 'n ongeluk betrokke sou raak. Die privaatambulans se broeikas toon leemtes in die gehalte-eienskappe van 'n broeikas, soos temperatuurhandhawing, luike, suurstofinlaatpunt, alternatiewe openinge en sigbaarheid van die neonaat (vergelyk tabel 6).

\section{Vervoerpersoneel}

Dit wil voorkom asof daar 'n leemte in die opleiding van, veral die privaatambulans, se vervoerpersoneel bestaan. Geen opleiding of ondervinding in die hantering van siek neonate word vereis nie en geen gestruktureerde indiensopleiding vind plaas nie. Gevolglik blyk dit dat die personeel nie oor die noodsaaklik vaardighede en kennis, soos resussitering, inwerkingstelling van infuus, behandeling van pneumotoraks, asook gepaardgaande medikasies en -toediening, beskik wat vereis word vir die vervoer van neonate nie (vergelyk tabel 6)

\section{GEVOLGTREKKINGS EN AANBEVELINGS}

Die beskikbaarheid van inligting betreffende die moederlike- en neonatale geskiedenis van neonate wat vervoer word blyk, veral by die privaatambulans wat siek neonate tussen hospitale vervoer, ntoereikend te wees.

Die gehalte van interhospitaalvervoer deur die provinsiale ambulans blyk beter as dié van die privaatambulans te wees. Hierdie gevolgtrekking is gebaseer op die volgende:

- Handhawing van die neonaat se temperatuur deur die privaatambulans was in al die vervoergevalle $(\mathrm{N}=11)$ ontoereikend met 'n daling in temperatuur nadat vervoer plaasgevind het. Geen daling in liggaamstemperatuur was by die steekproefpersone wat deur die provinsiale ambulans vervoer was $(\mathrm{N}=4)$ waargeneem nie.

- Die hart- en respiratoriese spoed van die steekproefpersone wat deur die privaatambulans vervoer is het dramaties toegeneem, naamlik ses vervoergevalle met 'n hartspoedtoename buite die normale spektrum en sewe met 'n respiratoriese spoed wat buite die normale spektrum ná vervoer waargeneem is $(\mathbf{N}=11)$.
- Die bloedglukosevlakke van drie steekproefpersone wat deur die privaatambulans vervoer is, was voor vervoer $\mathbf{4 5} \mathrm{mg} \%$ en het ná vervoer na 25 $\mathrm{mg} \%$ gedaal.

- Van die agt intra-veneuse oorgietings wat steekproefpersone in werking gehad het voordat vervoer plaasgevind het, was slegs vier ná vervoer deur die privaatambulans in werkende toestand. Die provinsiale ambulansvervoer het hier geen skade gely nie.

- Die skriftelike kommunikasie-stelsel van die privaatambulans toon geen inligting oor die toestand van die siek neonaat wat vervoer word nie.

- Die beskikbaarheid van toerusting wat bepalend vir die gehalte interhospitaalvervoer van siek neonate is, infuuspomp, suurstofanaliseerder, toerusting vir die dreinering van 'n pneumotoraks, asook die bepaling van privaatambulans.

- Geen gestruktureerde indiensopleiding word aan vervoerpersonel van die privaatambulans gegee nie.

Die gehalte van die interhospitaalvervoer van siek neonate deur ambulanse in die Witwatersrandarea is dus nie na wense nie. Die algehele afwesigheid van 'n multi-professionele komitee om die standaard van vervoer te moniteer bemoeilik die gehaltebeheer van hierdie interhospitaalvervoer.

Ten einde die gehalte van interhospitaalvervoer van siek neonate te verbeter, word die volgende aanbevelings gemaak:

- Die ontwerp, implementering en evaluering van 'n personeelontwikkelingsprogram vir ambulanspersoneel, veral ten opsigte van die resussitering en stabilisering van ' $n$ kritiek siek neonaat, die inwerkingstelling van ' $n$ intraveneuse oorgieting, temperatuur-, vogen suur-basishandhawing, pleurale dreinering en die toediening van noodmedikasie.

- Die daarstelling van 'n multiprofessionele komitee in die Witwatersrandarea met die doel om gehalte vervoer van siek neonate te verbeter.

- Die daarstelling van 'n nasionale liggaam wat beleid en standaarde rakende die vervoer van siek neonate neerlê en koördineer. byvoorbeeld die broeikas, 'n vitale tekens, toon leemtes by die
- Die standaardisering van die evalueringsinstrument.

\section{BEPERKINGE}

Aangesien hierdie studie binne kontekstuele verband in die Witwatersrandarea uitgevoer is het die resultate geen veralgemeningswaarde nie. Die gevallestudies kan, as gevolg van doelgerigte steekproeftrekking, nie as verteenwoordigend van die interhospitaalvervoer van siek neonate aan die Witwatersrandarea gereken word nie.

Slegs vyftien gevallestudies is beoordeel wat die statistiese verrekening van data bemoeilik. Selfs die betroubaarheidsdata van die instrument kan as gevolg van die klein steekproefgrootte $(N=15)$ nie as 'n akkurate weergawe van die betroubaarheid van die instrument gesien word nie.

Die waarnemers moes staatmaak op die ambulanspersoneel se verbale terugvoering ten opsigte van gebeure tydens die rit asook die vaardighede waaroor die vervoerpersoneel beskik. Die resultate kon moontlik hierdeur beïnvloed geword het.

Dit was vir die navorser as gevolg van etiese oorwegings, soos die hantering van krisis-situasies tydens die rit, onmoontlik om ritte mee te maak ten einde die kennis en vaardighede van die vervoerpersoneel te bepaal.

\section{BRONVERWYSINGS}

1. American Academy of Orthopaedic Surgeons. 1981. Emergency care and transportation of the sick and injured. Chicago: George Banta.

2. American Academy of Pediatrics. 1986 Committee on hospital care: guidelines for air and ground transportation of pediatric patients. Pediatrics, 5 (78), November, 943-949.

3. Andersen, E. 1979. Transport of high risk newborn infants. Danish Medical Bullerin. 3 (26), May, 147-149.

4. Cannon, J.A. 1983. Neonatal transport (In Avery, G.B ed.: Neonatology: Pathophysiology and management of the newborn). Philadelphia: JB Lippincott.

5. Crosse, V.M. 1975. The preterm baby and other babies with low birth-weight. New York: Churchill Livingstone.

6. Hood, J.L., Crosse, A., Hulka, B., Lawson, E.E. 1983. Effectiveness of the neonatal transport team. Critical Care Medicine, 6 (11), June, 419-423.

7. Schreiner, R.L. 1981. Care of the newborn. New York: Raven Press.

8. Vestall, K.W., McKenzie, S.A.M. 1983 High risk perinatal nursing. Philadelphia: WB Saunders.

\section{Erkennings}

1. Die Suid-Afrikaanse Verpleegstersvereniging vir die toekennning van 'n Florence Nightingale beurs.

2. Die Randse Afrikaanse Universiteit, Departement Verpleegkunde se navorsingseenheid vir finansiêle bystand.

Hierdie artikel is gebaseer op navorsing wat vir die graad M.CUR. (Verloskunde) aan die Randse Afrikaanse Universiteit gedurende 1988 onderneem is. 